\title{
AGRONOMIC RESPONSES TO THE INTENSIFICATION OF GRAIN PRODUCTION SYSTEMS IN DRYLAND FARMING OF CENTRAL MINAS GERAIS STATE, BRAZIL
}

Eduardo de Paula Simão ${ }^{1}$, Álvaro Vilela de Resende ${ }^{2}$, Jeferson Giehl ${ }^{1}$, João Carlos Cardoso

Galvão ${ }^{1}$, Émerson Borghi ${ }^{2}$, Antônio Carlos de Oliveira ${ }^{2}$, Miguel Marques Gontijo Neto ${ }^{2}$

${ }^{1}$ Federal University of Viçosa, Viçosa - Minas Gerais State, Brazil

E-mails: eduardosimao.agro@yahoo.com.br, jefergiehl@hotmail.com,jgalvao@ufv.br

${ }^{2}$ Embrapa Maize and Sorghum, Sete Lagoas - Minas Gerais State, Brazil

E-mails: alvaro.resende@embrapa.br, emerson.borghi@embrapa.br, antoniocarlos.oliveira@embrapa.br,

miguel.gontijo@embrapa.br

\section{ABSTRACT}

This work aimed to evaluate the agronomic responses to the intensification of grain production systems under water restriction in the central region of Minas Gerais State, Brazil. We studied six systems, including soybean and maize monocropping with medium investment in maintenance fertilization, and the annual alternating of these crops in medium or high investment, with inclusion or not of ruzigrass for straw increment. Soybean and maize in monocropping lose yield potential over time compared to their alternating cultivation. Greater fertilization in soil with built fertility does not increase the yield accumulated until the fourth harvest. The intercropping with ruzigrass can hamper maize yield under lower fertilization. The ruzigrass increases the average production of residues for straw formation in the soybean/maize system, approaching 8 ton.ha ${ }^{-1}$.year ${ }^{-1}$. After four crop seasons, differences in soil chemical attributes are still not evident due to the diversification/intensification of the production system.

Keywords: Water deficit, straw, diversification of crops

\section{RESPOSTAS AGRONÔMICAS À INTENSIFICAÇÃO DE SISTEMAS DE PRODUÇÃO DE GRÃOS EM SEQUEIRO NA REGIÃO CENTRAL DO ESTADO DE MINAS GERAIS, BRASIL}

\section{RESUMO}

Objetivou-se avaliar respostas agronômicas na intensificação de sistemas de produção de grãos sob restrição hídrica na região Central do Estado de Minas Gerais. Foram estudados seis sistemas, incluindo monocultivos de soja e de milho com médio investimento em adubação de manutenção, além dos cultivos alternados dessas espécies em médio ou alto investimento, com inserção ou não da braquiária para produção de palhada. Soja e milho em monocultura perdem 


\section{AGRONOMIC RESPONSES TO THE INTENSIFICATION OF GRAIN PRODUCTION SYSTEMS IN}

DRYLAND FARMING OF CENTRAL MINAS GERAIS STATE, BRAZIL

potencial produtivo com o tempo, em comparação ao seu cultivo alternado. Maior adubação de manutenção em solo de fertilidade construída não aumenta a produção de grãos acumulada até a quarta safra. Sob menor adubação, o consórcio com braquiária pode prejudicar a produtividade do milho. A braquiária aumenta o aporte médio de resíduos para palhada no sistema soja/milho, aproximando-se de 8 ton.ha- ${ }^{-1}$.ano ${ }^{-1}$. Após quatro safras, ainda são pouco evidentes diferenças nos atributos químicos do solo devido à diversificação/intensificação do sistema de produção.

Palavras-chave: Déficit hídrico, palhada, diversificação de culturas

\section{INTRODUCTION}

The central Cerrado of Minas Gerais State is largely favorable for the adoption of technified agriculture, but the climatic conditions are restrictive. Periods with low rainfall during the crop cycle, the so-called dry spells, can significantly hamper crop yield (CARVALHO et al., 2013) and are particularly more intense in this region, being one of the causes of the low expressiveness of cultivated area until the present.

The most common production systems under rainfed conditions are the monocropping of maize, sorghum and, less often, soybean. Rainfall distribution is insufficient to enable the succession of crops in the season/off-season modality in the region. Most producers do not adopt conservation practices, which leads to the loss of soil organic matter (SOM) and, consequently, degrades its agricultural suitability.

When good fertility conditions are provided, there is a stimulus for the growth of roots, which distribute along the profile due to the availability of nutrients (COSTA et al., 2009). This characteristic is important for water use efficiency (HATFIELD et al., 2001) and plant resistance to periods of lower water availability, as it enables water absorption in deeper layers, attenuating the effects of dry spells during the phase of higher water demand of crops, that is, flowering and grain filling.

In addition, ecological intensification with diversification of crops in rotation in the notillage system (NTS) and the inclusion of forage species such as Urochloa grasses in intercropping increase the quantity and quality of straw (CRUSCIOL et al., 2015; SÁ et al., 2015), protecting the soil, besides favoring nutrient cycling (MOMESSO et al., 2019; TANAKA et al., 2019) and biological activity (MENDES et al., 2019). 
Although it is still a challenge for producers to combine straw quantity and quality with plant residues that are diversified and at different stages of decomposition, an environment thus constituted is more favorable to the increase of SOM levels (SÁ et al., 2015; VELOSO et al., 2018), benefiting the root development of crops. If well conducted, the intensification in NTS tends to maintain or improve soil fertility. As a result, greater potential, stability and production efficiency are expected, with resilience to climate stresses.

Given the constraints for the advance of grain production in Cerrado biome regions with more pronounced water restriction, this study aimed to evaluate the agronomic performance of intensified systems under rainfed conditions, involving species diversification and fertilizer investment in the central region of Minas Gerais, Brazil.

\section{MATERIAL AND METHODS}

The study was conducted under rainfed conditions at Embrapa Milho e Sorgo (19 $28^{\prime} 36^{\prime \prime}$ S latitude, $44^{\circ} 11$ ' 53 " W longitude, and altitude of $732 \mathrm{~m}$ ), in Sete Lagoas, state of Minas Gerais, Brazil, for four crop seasons (2014/15 to 2017/18). The climate of the region is classified as Cwa according to Köppen's classification (with dry winter and hot summer), with an average annual temperature of $21.8{ }^{\circ} \mathrm{C}$ and average annual rainfall of $1,345 \mathrm{~mm}$. Rainfall data during the crop seasons are presented (Figure 1).

The soil, classified as a clayey dystrophic Red Latosol (Oxisol) (660 g. $\mathrm{kg}^{-1}$ clay), had the following average fertility conditions in the $0-0.2 \mathrm{~m}$ layer before the installation of the experiment: $\mathrm{pH}$ in water $=5.4$; organic matter $=35 \mathrm{~g}^{\mathrm{kg}} \mathrm{kg}^{-1} ; \mathrm{P}$ and $\mathrm{K}$ contents (Mehlich 1 extractant $)=2.4$ and $17.3 \mathrm{mg} \cdot \mathrm{dm}^{-3}$, respectively; $\mathrm{Ca}$ and $\mathrm{Mg}$ contents $=3.8$ and $0.9 \mathrm{cmol}_{\mathrm{c} .} . \mathrm{dm}^{-3}$, respectively; base saturation $(\mathrm{V})=39 \%$; and $\mathrm{Al}$ saturation $(\mathrm{m})=4.8 \%$.

In 2014, the entire experimental area was subjected to chiseling to about $25 \mathrm{~cm}$ deep and application of dolomitic limestone (4.0 ton.ha $\left.{ }^{-1}\right)$ incorporated with a moldboard plow and a plowing harrow. Then, phosphogypsum (3.0 ton.ha $\left.{ }^{-1}\right)$, single superphosphate (1 ton.ha ${ }^{-1}$ ), potassium chloride $\left(300 \mathrm{~kg} \cdot \mathrm{ha}^{-1}\right)$ and fritted trace elements - FTE $\left(90 \mathrm{~kg}^{-h a^{-1}}\right)$ were applied and incorporated with leveling harrow at $10 \mathrm{~cm}$ depth. These procedures were based on the recommendations of Sousa \& Lobato (2004) and aimed at the correction of soil acidity and "construction" of its fertility in the profile for no-tillage management. 


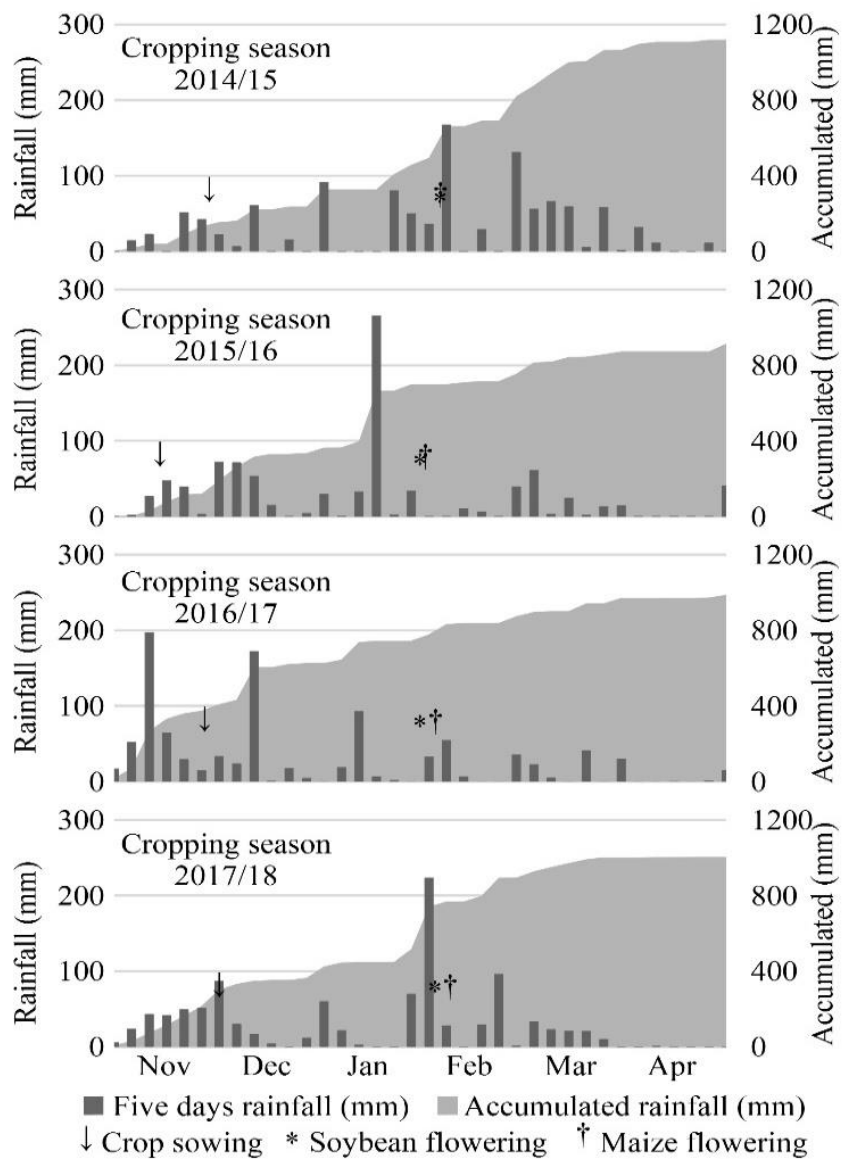

Figure 1. Rainfall distribution by five-day periods and total accumulated in each crop season, Sete Lagoas, Minas Gerais State, Brazil, 2018.

The area has about four hectares, with uniform slope, and was divided to accommodate six treatments of intensification of production systems. This intensification involved species diversification and two levels of investment in the maintenance fertilizer (Figure 2). The treatments were formed as follows: System 1 - Soybean monocropping with medium investment in fertilizer (Sm); System 2 - Maize monocropping with medium investment (Mm); System 3 Annual succession of soybean and maize with medium investment (SMm); System 4 Succession of soybean and maize with inclusion of the ruzigrass (Urochloa ruziziensis) to increase straw, with medium investment (SMRm); System 5 - Succession of soybean and maize with high investment (SMh); and System 6 - Succession of soybean and maize, with inclusion of ruzigrass, with high investment (SMRh).

The systems involving medium investment corresponded to the nutritional management representative of the standard used in the region, while the high investment systems receive a 
higher supply of fertilizers in maintenance NPK fertilization (Figure 2) and foliar applications of macronutrients and micronutrients in soybean $\left(5 \mathrm{~kg} \mathrm{ha}^{-1}\right.$ of Monoammonium Phosphate and 3 kg.ha ${ }^{-1}$ of Calcium Nitrate in 2014/15 and 2 L.ha $^{-1}$ of the nutrient cocktail Quimifol Cerrado ${ }^{\circledR}$ in 2016/17). Under high investment, dolomitic limestone was also reapplied on the surface (3.3 ton.ha ${ }^{-1}$ ), preceding the $2016 / 17$ crop season.

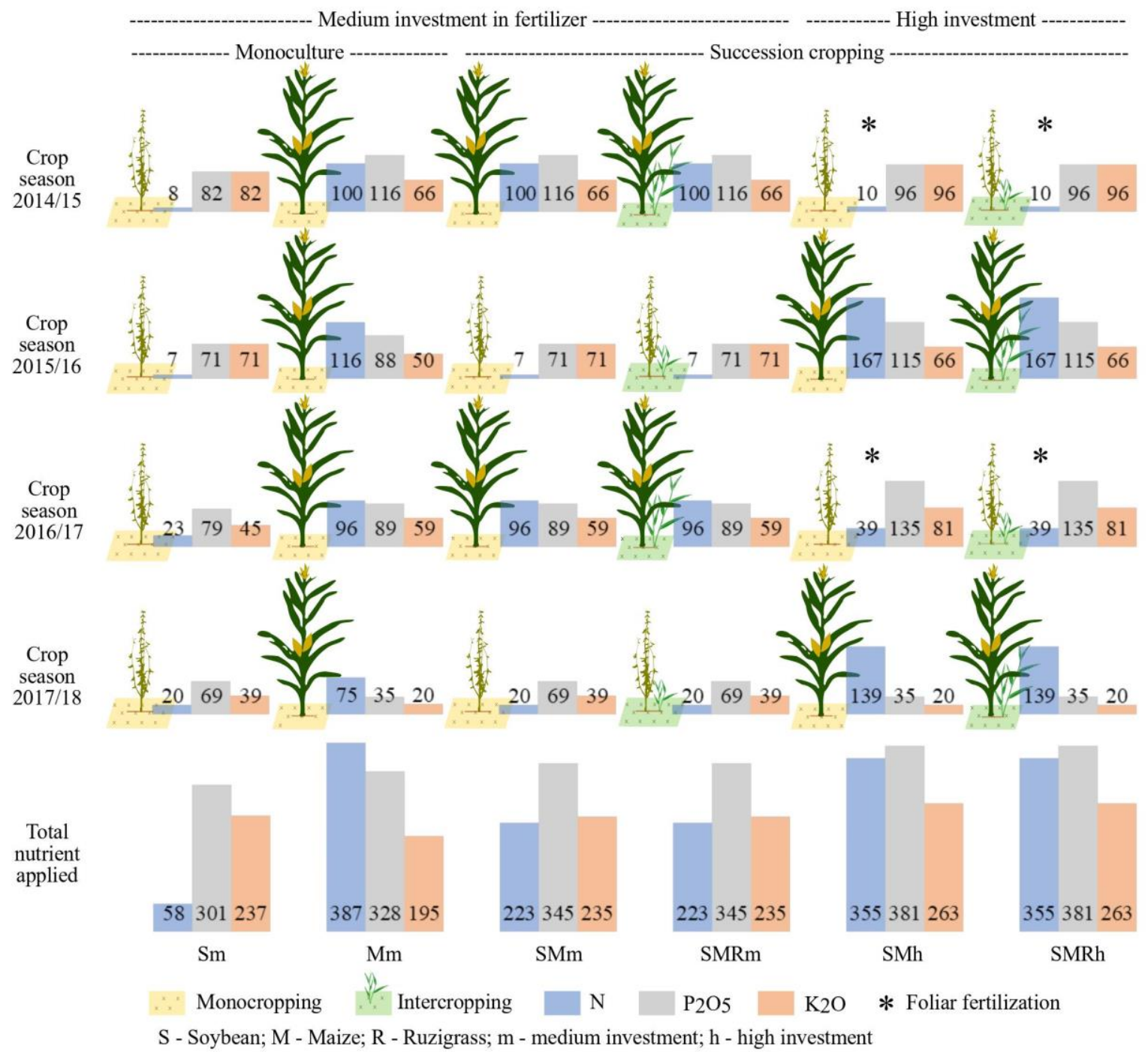

Figure 2. Sequence of crops and fertilizer nutrient inputs $\left(\mathrm{kg} \cdot \mathrm{ha}^{-1}\right)$ for each production system, in the four evaluated crop seasons, Sete Lagoas, Minas Gerais State, Brazil, 2018.

The spacing used between rows was $0.5 \mathrm{~m}$ for soybean and $0.7 \mathrm{~m}$ for maize. The soybean cultivars used in each crop season were BRS 7380 RR, BRS 8081 RR, RK 5813 RR, and RK 6813 RR, respectively, while the maize cultivars were AS 1581 PRO in the 2014/15 crop season and AG 8088 PRO2 in the following ones. In the systems with inclusion of ruzigrass, the grass 


\section{AGRONOMIC RESPONSES TO THE INTENSIFICATION OF GRAIN PRODUCTION SYSTEMS IN DRYLAND FARMING OF CENTRAL MINAS GERAIS STATE, BRAZIL}

seeds were distributed mixed to the fertilizer in the sowing furrow of maize and broadcast during the reproductive stage of soybean (phenological stage R5.5), according to Andrade et al. (2017).

The experiment sought to reproduce environments of plantations, requiring large dimensions for better expressing the conditions that result from the systems/treatments. This required the use of large machinery, so it was not possible to use a classic experimental design, with true statistical replicates. Thus, data from evaluations of the crops were obtained with pseudo-replicates (FERREIRA et al., 2012; CECAGNO et al., 2016), by means of independent samples at ten random points, georeferenced within the area destined for each system.

Grain yield was evaluated after physiological maturity, by harvesting three rows of three meters in length close to each georeferenced point and correcting the moisture content to $13 \%$. At harvest, the production of plant residue dry biomass was also quantified, individualizing the contribution from ruzigrass in the respective treatments. Ruzigrass remained in free growth during the off-season.

The existing amount of straw, prior to the sowing of the 2015/16 crop season (first in notillage) and 2018/19 crop season (after the four harvests of the present study), was estimated by sampling of $1 \mathrm{~m}^{2}$ close to the georeferenced points. In December 2014, composite soil samples were collected at depths of 0-0.1, 0.1-0.2 and 0.2-0.4 $\mathrm{m}$ at these points to characterize the systems after the incorporation of inputs for profile conditioning. In November 2018, a new sampling was performed to monitor the evolution of fertility attributes after four crop seasons. In this case, nine single samples were collected around each georeferenced point, three in the row of the last crop and six between the rows. Laboratory analyses followed the methodologies described in Teixeira et al. (2017).

The data were subjected to analysis of variance with software Sisvar (FERREIRA, 2019), considering a completely randomized design and ten independent sampling units within each system as replicates (pseudo-replicates). Means of the variables were compared using the LSD test at $5 \%$ probability level. As the sequence of crops throughout the crop seasons was not the same for all treatments (Figure 2), the analyses for grain yield were applied to subsets of data in order to allow checking the responses of soybean and maize, individually and jointly in the succession. 


\section{RESULTS AND DISCUSSION}

In the first year of the experiment (2014/15), soybean grain yield did not differ as a function of the production systems (Table 1). The absence of difference at this initial moment of establishment of the Sm, SMh and SMRh systems was expected, due to procedures of soil tillage and initial conditioning of fertility. Thus, the 'constructed' fertility nullified possible effects of the intensification process, which until then was restricted to the increase in maintenance fertilizer (Figure 2), considering that the ruzigrass oversown in the soybean maturation stage has no interference in the yield of the respective harvest (ANDRADE et al., 2017).

Due to the dynamics of alternation of crops in the subsequent crop seasons (Figure 2), the simultaneous cultivation of soybean in the $\mathrm{Sm}, \mathrm{SMh}$ and $\mathrm{SMRh}$ systems occurred again in 2016/17, in the third agricultural year. In this season, the treatments combining soybean/maize succession and high investment in maintenance fertilizer, with or without the inclusion of ruzigrass for straw, had higher soybean yield than that obtained in the monocropping system with medium investment (Table 1).

It is observed that the production potential in $2016 / 17$ was lower than in $2014 / 15$, with a significant reduction in soybean yield in the three systems (Table 1). The probable cause was the more limiting climatic condition, with periods without rains during the cycle in 2016/17, notably before and at the beginning of flowering (Figure 1). According to Battisti \& Sentelhas (2015), the period of greater sensitivity of soybean to water deficit is from flowering (R1 stage) to grain filling (R5 stage).

Under these circumstances, the soil cover provided by the succession with maize becomes important, as it leaves a large amount of residues with high $\mathrm{C} / \mathrm{N}$ ratio, besides the significant increase of biomass by Urochloa grasses (MATEUS et al., 2020). These forms of intensification of the production system provided better conditions for soybean to withstand periods of low rainfall, resulting in higher grain yields compared to monocropping (Table 1).

In the 2015/16 and 2017/18 crop seasons, soybean was cultivated in treatments with medium investment in fertilizer (Table 1). In 2015/16, the second year of the experiment, there was still no difference between the systems, while in 2017/18, the yield in monocropping was significantly lower, reiterating the reduction already detected in the previous agricultural year compared to systems with high fertilizer investment. 
Table 1. Soybean grain yield $\left(\mathrm{kg}_{\mathrm{h}} \mathrm{ha}^{-1}\right)$ in response to the intensification of rainfed production systems, in the central Cerrado of Minas Gerais State, Brazil.

System

$$
\text { Crop season }
$$

Soybean monocropping, medium investment (Sm)

$2014 / 15 \quad 2016 / 17$

Soybean/Maize, high investment (SMh)

$\begin{array}{ll}2,917 \mathrm{aA} & 1,499 \mathrm{bB} \\ 3,073 \mathrm{aA} & 2,327 \mathrm{aB} \\ 3,076 \mathrm{aA} & 2,462 \mathrm{aB}\end{array}$

Soybean/Maize/Ruzigrass, high investment (SMRh)

\begin{tabular}{lc}
\hline Mean & 3,021 \\
\hline System & $\rho<0.001$ \\
Crop season & $\rho<0.001$ \\
System x Crop season & $\rho<0.001$ \\
\hline
\end{tabular}

System

Crop season

Soybean monocropping, medium investment (Sm)

2015/16 2017/18

Soybean/Maize, medium investment (SMm)

$3,248 \mathrm{aA} \quad 2,211 \mathrm{bB}$

Soybean/Maize/Ruzigrass, medium investment (SMRm)

$3,047 \mathrm{aA} \quad 3,259 \mathrm{aA}$

Mean

$2,930 \mathrm{aB}$ 3,335 aA

System

3,075

2,935

Crop season

$\rho=0.028$

System x Crop season

$\rho=0.136$

$\rho<0.001$

$\rho:$ p-value by $\mathrm{F}$ test. Means followed by the same letter, uppercase in the row and lowercase in the column, do not differ statistically by LSD test at $5 \%$ probability level.

The benefit of crop succession is clear because, over time, soybean monocropping (Sm) lost yield potential compared to the more diversified systems, at any level of investment (Table 1). Throughout the four seasons, it was confirmed that soybean monocropping is a less sustainable option, for reasons that have been well documented in the literature (SANTOS et al., 2014; RESENDE et al., 2016; MENDES et al., 2019), including the deterioration of attributes related to soil quality.

The inclusion of the intercropped ruzigrass in maize crops or in oversowing of soybean (SMRh and SMRm) did not increase its yield compared to the soybean/maize succession system 
and led to lower production in the 2015/16 season compared to the 2017/18 season (Table 1). Some gain in yield was expected due to the effect of ruzigrass increasing the amount of straw existing at the time of soybean sowing in 2015/16 (Table 2).

Table 2. Straw (ton.h $\mathrm{a}^{-1}$ ) present at the time of sowing and plant residues biomass on dry basis (ton.ha ${ }^{-1}$ ) estimated after harvesting the grains along four crop seasons, in response to the intensification of rainfed production systems, in the central Cerrado of Minas Gerais State, Brazil, 2018.

\begin{tabular}{|c|c|c|c|c|c|}
\hline \multirow[b]{2}{*}{ Systems } & \multicolumn{2}{|c|}{ Straw at sowing } & \multicolumn{3}{|c|}{ Plant biomass at harvest } \\
\hline & $\begin{array}{c}2015 / 16 \\
\text { (Initial) }\end{array}$ & $\begin{array}{c}2018 / 19 \\
\text { (Final) }\end{array}$ & $\begin{array}{c}\text { Total of four } \\
\text { seasons }\end{array}$ & $\begin{array}{l}\text { Contribution from } \\
\text { ruzigrass (two } \\
\text { seasons intercropped } \\
\text { with maize) }\end{array}$ & $\begin{array}{l}\text { Average } \\
\text { annual } \\
\text { supply }\end{array}$ \\
\hline $\mathrm{Sm}$ & $2.3 \mathrm{c}$ & $0.7 \mathrm{c}$ & $10.9 \mathrm{e}$ & 0 & $2.7 \mathrm{e}$ \\
\hline $\mathrm{Mm}$ & $7.5 \mathrm{ab}$ & $5.9 \mathrm{a}$ & $33.2 \mathrm{a}$ & 0 & $8.3 \mathrm{a}$ \\
\hline $\mathrm{SMm}$ & $6.7 \mathrm{~b}$ & $2.1 \mathrm{~b}$ & $25.7 \mathrm{c}$ & 0 & $6.4 \mathrm{c}$ \\
\hline SMRm & $8.4 \mathrm{a}$ & $3.3 \mathrm{~b}$ & $32.2 \mathrm{a}$ & 4.4 & $8.0 \mathrm{a}$ \\
\hline SMh & $3.5 \mathrm{c}$ & $5.2 \mathrm{a}$ & $23.5 \mathrm{~d}$ & 0 & $5.9 \mathrm{~d}$ \\
\hline SMRh & $8.0 \mathrm{ab}$ & $6.3 \mathrm{a}$ & $28.8 \mathrm{~b}$ & 2.3 & $7.2 \mathrm{~b}$ \\
\hline p-value & $\rho<0.001$ & $\rho<0.001$ & $\rho<0.001$ & - & $\rho<0.001$ \\
\hline
\end{tabular}

This absence of benefits of ruzigrass on soybean performance in the present study corroborates the report by Mendes et al. (2019), about non-significant responses to the intensification in the first six years with succession and rotation schemes involving soybean, maize, Urochloa grass, millet and/or crotalaria in Mato Grosso State, Brazil. However, it contrasts with positive short-term results reported by studies in other regions (ALVES et al., 2013; CECCON et al., 2013; ANDRADE et al., 2017).

In the first year (2014/15), maize was cultivated in treatments with medium fertilizer investment, which did not differ in grain yield (Table 3). The performance of the monocropping system (Mm) was similar to that of those with crop succession (SMm and SMRm) because there is still no difference in the management history until then, except for the presence of ruzigrass in the intercropping treatment. 


\section{AGRONOMIC RESPONSES TO THE INTENSIFICATION OF GRAIN PRODUCTION SYSTEMS IN DRYLAND FARMING OF CENTRAL MINAS GERAIS STATE, BRAZIL}

Table 3. Maize grain yield $\left(\mathrm{kg} \cdot \mathrm{ha}^{-1}\right)$ in response to the intensification of rainfed production systems, in the central Cerrado of Minas Gerais State, Brazil.

System

$$
\text { Crop season }
$$

Maize monocropping, medium investment (Mm)

$2014 / 15 \quad 2016 / 17$

Soybean/Maize, medium investment (SMm)

$\begin{array}{cc}9,337 \mathrm{aA} & 10,021 \mathrm{aA} \\ 9,850 \mathrm{aA} & 10,308 \mathrm{aA} \\ 9,197 \mathrm{aA} & 8,921 \mathrm{bA}\end{array}$

Soybean/Maize/Ruzigrass, medium investment (SMRm)

\begin{tabular}{lc}
\hline Mean & 9,461 \\
\hline System & $\rho=0.001$ \\
Crop season & $\rho=0.207$ \\
System x Crop season & $\rho=0.204$ \\
\hline
\end{tabular}

\begin{tabular}{lc}
\hline Mean & 9,461 \\
\hline System & $\rho=0.001$ \\
Crop season & $\rho=0.207$ \\
System x Crop season & $\rho=0.204$ \\
\hline
\end{tabular}

System

Crop season

Maize monocropping, medium investment (Mm)

2015/16 2017/18

Soybean/Maize, high investment (SMh)

$\begin{array}{cc}8,147 \mathrm{cA} & 8,566 \mathrm{bA} \\ 9,107 \mathrm{bB} & 10,962 \mathrm{aA} \\ 10,362 \mathrm{aA} & 10,308 \mathrm{aA}\end{array}$

Soybean/Maize/Ruzigrass, high investment (SMRh)

9,206

9,945

System

$$
\rho<0.001
$$

Crop season

$\rho=0.002$

System x Crop season

$\rho=0.004$

$\rho$ : p-value by $\mathrm{F}$ test. Means followed by the same letter, uppercase in the row and lowercase in the column, do not differ statistically by the LSD test at 5\% probability level.

In the 2016/17 crop season, with maize again in the systems under medium investment, the intercropping with ruzigrass (SMRm) significantly compromised grain yield (Table 3). Possibly, the greater competition for nutrients, notably nitrogen $(\mathrm{N})$, aggravated by water restriction at the vegetative development stage (Figure 1), delayed canopy closure, hence disfavoring maize.

This situation contrasts with what was observed in 2015/16, when the intercropping with ruzigrass did not interfere in maize yield under higher level of fertilizer (SMRh). On the contrary, this treatment was the most productive in that year (Table 3) and seems to have benefited from the history of system intensification. This is because, in addition to the greater supply of fertilizer 
nutrients, the increase of straw by the ruzigrass oversown in the previous soybean crop (Table 2) possibly mitigated the effects of rainfall scarcity before and after maize flowering (Figure 1), to the point of neutralizing the losses suffered in the other two systems (SMh and Mm). The flowering stage of maize is the most sensitive to water deficit (ANDRIOLI \& SENTELHAS, 2009) and any factor that favors the maintenance of soil moisture during this period can be decisive for grain yield.

In the accumulated response of four crop seasons, the intensification with ruzigrass led to the loss of overall yield of the soybean/maize succession system under medium investment (Table 4). The higher value of ruzigrass biomass in the harvest of the intercropping with maize in this treatment (Table 2) demonstrates that, if the supply of nutrients is limited, maize has more difficulty in exerting dominance over the grass.

Table 4. Accumulated grain yield $\left(\mathrm{kg} \cdot \mathrm{ha}^{-1}\right)$, after four crop seasons with alternating cultivation of soybean and maize, in response to the intensification of rainfed production systems, in the central Cerrado of Minas Gerais, Brazil, 2018.

\begin{tabular}{lcc}
\hline \multirow{2}{*}{ Inclusion of ruzigrass } & \multicolumn{2}{c}{ Investment in fertilizer } \\
\cline { 2 - 3 } & Medium & High \\
\hline Without ruzigrass & $26,464 \mathrm{aA}$ & $25,469 \mathrm{aA}$ \\
With ruzigrass & $24,383 \mathrm{bB}$ & $26,207 \mathrm{aA}$ \\
\hline Mean & 25,423 & 25,838 \\
\hline Investment in fertilizer & & $\rho=0.375$ \\
Ruzigrass & & $\rho=0.154$ \\
Investment x Ruzigrass & & $\rho=0.004$ \\
\hline
\end{tabular}

$\rho$ : p-value by $\mathrm{F}$ test. Means followed by the same letter, uppercase in the row and lowercase in the column, do not differ statistically by the LSD test at $5 \%$ probability level.

Ruzigrass growth is strongly stimulated by the incidence of sunlight (BORGHI et al., 2013), and shading is an efficient factor to control its development. Water and nutritional stresses, which delay the canopy closure of maize in intercropped crops (RESENDE et al., 2019), favor ruzigrass and enhance interspecific competition, negatively affecting grain yield. The intercropping with ruzigrass interferes with the amount of $\mathrm{N}$ requirement, also influencing interspecific competition, so fertilizing should be higher in systems with greater competition (MATEUS et al., 2020).

Figure 3 shows the attributes of soil analysis, with the mean after the applications of limestone, phosphogypsum and corrective fertilizer for initial profile conditioning and the value measured in each system after four crop seasons. In general, after four seasons, all treatments 


\section{AGRONOMIC RESPONSES TO THE INTENSIFICATION OF GRAIN PRODUCTION SYSTEMS IN DRYLAND FARMING OF CENTRAL MINAS GERAIS STATE, BRAZIL}

showed soil fertility conditions interpreted as adequate, according to Sousa \& Lobato (2004). With the possibility of phosphorus $(\mathrm{P})$ and potassium $(\mathrm{K})$ deficiency being excluded, the premise that the adjustment in $\mathrm{N}$ supply is a strong conditioning factor so that there is no harmful competition in the cultivation of maize intercropped with tropical forage grasses is reinforced.

The experiment was conducted with periods of water restriction (Figure 1) and high temperatures during the season, characteristic of the central region of Minas Gerais. These factors certainly influenced so that the yield level according to the genetic potential of the cultivars were not reached. Even in the systems with the highest fertilizer investment, the harvests were limited (Tables 1 and 3), as well as the export of nutrients in the grains. The low removal ultimately contributed to prolonging the effects of the initial conditioning of soil fertility (Figure 3).

As with soybean, maize monocropping was more susceptible to production instability. Despite accumulating more straw residues over time (Table 2), the recurrent cultivation of maize (Mm) did not increase SOM contents (Figure 3) and showed a decrease of yield (Table 3).

Extreme situations were represented by soybean $(\mathrm{Sm})$ and maize $(\mathrm{Mm})$ monocropping, responsible for the smallest and largest additions of crop residues, respectively (Table 2). Despite leaving a large amount of residues, maize monocropping does not favor soil quality due to the high $\mathrm{C} / \mathrm{N}$ ratio of its straw (SÁ et al., 2010). On the other hand, soybean monocropping produces residue in small amounts and with very fast decomposition due to the low $\mathrm{C} / \mathrm{N}$ ratio, causing low soil protection and loss of nutrients and SOM due to erosion (COSTA et al., 2013; MENDES et al., 2019).

Therefore, the ideal would be the rotation of several grass and legume species in NTS, promoting differentiated flows of $\mathrm{C}$ and $\mathrm{N}$, in a variation that maximizes the accumulation of SOM. Systems capable of producing a large amount of residues of different $\mathrm{C} / \mathrm{N}$ ratios can recover the original levels of SOM in a relatively short period (SÁ et al., 2015). The presence of legumes enriches the system with $\mathrm{N}$, increasing the stocks of total carbon and total nitrogen, components of the greatest relevance for the production potential of the soil (VELOSO et al., 2018).

The contribution of ruzigrass to the straw formed for the 2015/16 season (Table 2) was noticeable, due to the higher contribution of plant residues from the first crop in intercropping with maize (SMRm in 2014/15) or oversowing in soybean (SMRh in 2014/15). The contribution of the residues generated by ruzigrass also influenced the sum of four seasons of biomass 
quantified at the harvests, the average annual supply of biomass and the straw at the end of 2018 (Table 2).
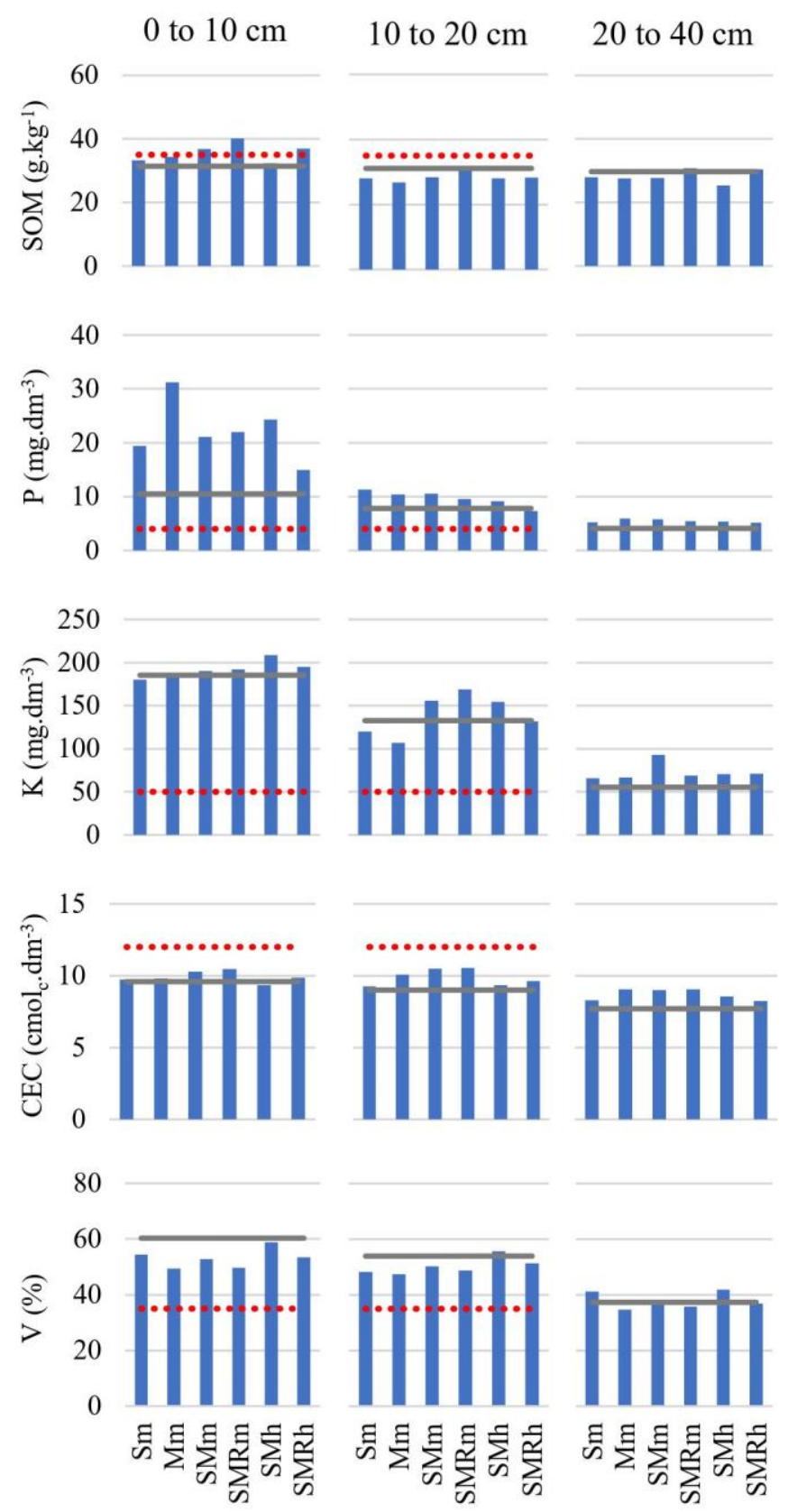

- Initial $\square$ After four harvests $\quad \mathbf{m}=\mathbf{=}=$ Critical level

S - Soybean; M - Maize; R - Ruzigrass;

$\mathrm{m}$ - medium investment in fertilization; $\mathrm{h}$ - high investment

Figure 3. Soil attributes in the layers of 0-10, $10-20$ and 20-40 $\mathrm{cm}$ deep. Mean values after initial conditioning (2014) and values after four harvests (2018) in response to the intensification of rainfed grain production systems, in the central Cerrado of Minas Gerais, Brazil. Critical levels according to Sousa \& Lobato (2004). 


\section{AGRONOMIC RESPONSES TO THE INTENSIFICATION OF GRAIN PRODUCTION SYSTEMS IN DRYLAND FARMING OF CENTRAL MINAS GERAIS STATE, BRAZIL}

Values of average annual supply of residues close to 8 ton.ha $^{-1}$ at harvest (Table 2) indicate that maize in monocropping $(\mathrm{Mm})$ and soybean/maize succession with inclusion of ruzigrass (SMRm and SMRh) promoted better soil cover. However, it would be desirable for grain production systems in the central Cerrado of Minas Gerais to leave larger amounts of crop residues on the soil. The literature reports that annual dry biomass additions of around 12.5 ton.ha $\mathrm{a}^{-1}$ are needed to maintain the sustainability of NTS in tropical regions and 8.5 ton.ha $^{-1}$ in subtropical regions (SÁ et al., 2015).

Nevertheless, the trend of SOM accumulation after four seasons in some of the treatments, in the $0-10 \mathrm{~cm}$ layer (Figure 3), is an indication that something around 8 ton.ha $^{-1}$ of residues generated at harvest would be a minimum goal for the central region of Minas Gerais. In the absence of conclusive data, this value may constitute a preliminary regional reference, a critical limit to prevent soil quality degradation and the loss of sustainability in the annual succession systems of crops under no-tillage.

Urochloa grasses have increased SOM in subsurface as a result of abundant root development and of root system renewal process, favoring grain production systems (CRUSCIOL et al., 2015). However, in the present study it was not yet possible to consistently detect effects of systems with ruzigrass on SOM contents and other attributes of soil chemical fertility (Figure 3).

It is usually necessary a longer time of adoption so that systems with different levels or modalities of intensification can exhibit significant changes in routine soil fertility analyses (MENDES et al., 2019). Until the fifth year, the NTS is still in the initial stage of establishment and, only when consolidated, after the tenth year, promotes full benefits for soil attributes and crop performance (SÁ et al., 2010). These facts reinforce the relevance of research results consolidated in a long term for consistent indications of intensification strategies adapted to the Cerrado of the central region of Minas Gerais.

\section{CONCLUSION}

The production systems with soybean and maize in monocropping confirm that there is a loss of yield potential over time, compared to the annual succession.

The higher investment in maintenance fertilizer in the soil with previously built fertility does not promote an increase in the grain yield accumulated until the fourth harvest. 
Under lower fertilizer investment, especially due to nitrogen insufficiency, the intercropping with ruzigrass hampers maize yield.

With the inclusion of ruzigrass, the average supply of residues for straw formation in the soybean/maize annual succession increases, approaching 8 ton.ha $^{-1}$ year $^{-1}$.

After four crop seasons, the differences in soil chemical attributes are still not evident due to the diversification/intensification of the grain production system.

\section{ACKNOWLEDGEMENTS}

To Brazilian National Council for Scientific and Technological Development (Process 422538/2016-7) and to Agrisus Foundation (Process 1491/15) for financial support and to the Brazilian Coordination for the Improvement of Higher Education Personnel and Brazilian National Council for Scientific and Technological Development for the scholarships granted.

\section{REFERENCES}

ALVES, V. B.; PADILHA, N. D. S.; GARCIA, R. A.; CECCON, G. 2013. Milho safrinha consorciado com Urochloa ruziziensis e produtividade da soja em sucessão. Revista Brasileira de Milho e Sorgo, Sete Lagoas, v. 12, n. 3, p. 280-292. https://doi.org/10.18512/1980-6477/rbms.v12n3p280-292

ANDRADE, C. A. O. D.; BORGHI, E.; BORTOLON, L.; BORTOLON, E. S. O.; CAMARGO, F. P. D.; AVANZI, J. C.; SIMON, J.; SILVA, R. R.; FIDELIS, R. R. 2017. Straw production and agronomic performance of soybean intercropped with forage species in no-tillage system. Pesquisa Agropecuária Brasileira, Brasília v. 52, n. 10, p. 861-868. http://dx.doi.org/10.1590/S0100-204X2017001000005

ANDRIOLI, K. G.; SENTELHAS, P. C. 2009. Brazilian maize genotypes sensitivity to water deficit estimated through a simple crop yield model. Pesquisa Agropecuária Brasileira, Brasília, v. 44, n. 7, p. 653-660, 2009. https://doi.org/10.1590/S0100-204X2009000700001

BATTISTI, R.; SENTELHAS, P. 2015. Drought tolerance of Brazilian soybean cultivars simulated by a simple agrometeorological yield model. Experimental Agriculture, Cambridge, v. 51, n. 2, p. 285-298. https://doi.org/10.1017/S0014479714000283

BORGHI, É.; CRUSCIOL, C. A. C.; NASCENTE, A. S.; MATEUS, G. P.; MARTINS, P. O.; COSTA, C. 2013. Effects of row spacing and intercrop on maize grain yield and forage production of palisade grass. Crop and Pasture Science, Melbourne, v. 63, n. 12, p. 11061113. https://doi.org/10.1071/CP12344

CARVAlHO, J. R. P.; ASSAD, E. D.; EVANGELISTA, S. R. M.; PINTO, H. S. 2013. Estimation of dry spells in three Brazilian regions - Analysis of extremes. Atmospheric Research, Amsterdam, $\quad$ v. $\quad 132-133, \quad$ p. http://dx.doi.org/10.1016/j.atmosres.2013.04.003

CECAGNO, D.; COSTA, S. E. V. G. A.; ANGHINONI, I.; KUNRATH, T. R.; MARTINS, A. P.; REICHERT, J. M.; GUBIANI, P. I.; BALERINI, F.; FINK, J. R.; CARVALHO, P. C. F. 
2016. Least limiting water range and soybean yield in a long-term, no-till, integrated crop livestock system under different grazing intensities. Soil \& Tillage Research, Amsterdam, v. 156, p. 54-62. http://dx.doi.org/10.1016/j.still.2015.10.005

CECCON, G.; STAUT, L. A.; SAGRILO, E.; MACHADO, L. A. Z.; NUNES, D. P.; ALVES, V. B. 2013. Legumes and forage species sole or intercropped with corn in soybean-corn succession in Midwestern Brazil. Revista Brasileira de Ciência do Solo, Viçosa, v. 37, n. 1, p. 204-212. http://dx.doi.org/10.1590/S0100-06832013000100021

COSTA, S. E. V. G. DE; SOUZA, E. D. DE; ANGHIONI, I.; FLORES, J. P. C.; CAO, E. G.; HOLZSCHUH, M. J. 2009. Phosphorus and root distribution and corn growth as related to long-term tillage systems and fertilizer placement. Revista Brasileira de Ciência do Solo, Viçosa, v. 33, n. 5, p. 1237-1247. https://doi.org/10.1590/S0100-06832009000500017

COSTA, E. M. DA; SILVA, H. F.; RIBEIRO, P. R. A. 2013. Matéria orgânica do solo e o seu papel na manutenção e produtividade dos sistemas agrícolas. Enciclopédia Biosfera, Jandaia, v. 9, n. 17, p. 1842-1860.

CRUSCIOL, C. A.; NASCENTE, A. S.; BORGHI, E.; SORATTO, R. P.; MARTINS, P. O. 2015. Improving soil fertility and crop yield in a tropical region with palisade grass cover crops. Agronomy Journal, Madison, v. 107, p. 2271-2280. https://doi.org/10.2134/agronj14.0603

FERREIRA, D. F. 2019. Sisvar: A computer analysis system to fixed effects split plot type designs. Revista Brasileira de Biometria, Lavras, v. 37, n. 4, p. 529-535. https://doi.org/10.28951/rbb.v37i4.450

FERREIRA, D. F.; CARGNELUTTI FILHO, A.; LÚCIO, A. D. 2012. Procedimentos estatísticos em planejamentos experimentais com restrição na casualização. Boletim Informativo Sociedade Brasileira de Ciência do Solo. Viçosa: SBCS, v. 37, n. 3, p. 16-19.

HATFIELD, J. L.; SAUER, T. J.; PRUEGER, J. H. 2001. Managing Soils to Achieve Greater Water Use Efficiency: A Review. Agronomy Journal, Madison, v. 93, p. 271-280. https://doi.org/10.2134/agronj2001.932271x

MATEUS, G.P.; CRUSCIOL, C.A.C.; PARIZ, C.M.; COSTA, N. R.; BORGHI, E.; COSTA, C. MARTELLO, J. CASTILHOAS, A. M.; FRANZLUEBBERS, A. J.; CANTARELLA, H. 2020. Corn intercropped with tropical perennial grasses as affected by side dress nitrogen application rates. Nutrient Cycling in Agroecosystems, Heidelberg, v. 116, p. 223-244. https://doi.org/10.1007/s10705-019-10040-1

MENDES, I. C.; SOUSA, D. M. G. DE; REIS JUNIOR, F. B. DOS; LOPES, A. A. C.; SOUZA, L. M. DE; CHAER, G. M. 2019. Bioanálise de solo: aspectos teóricos e práticos. In: SEVERIANO, E. DA C.; MORAES, M. F. DAS; PAULA, A. M. DE (Ed.) Tópicos em ciência do solo. Viçosa: SBCS, $10^{\text {th }}$ vol. p. 399-462.

MOMESSO, L.; CRUSCIOL, C. A.; SORATTO, R. P.; VYN, T. J.; TANAKA, K. S.; COSTA, C. H.; NETO, J. F.; CANTARELLA, H. 2019. Impacts of Nitrogen Management on No-Till Maize Production Following Forage Cover Crops. Agronomy Journal, Madison, v. 111, p. 639-649. https://doi.org/10.2134/agronj2018.03.0201

RESENDE, A. V.; FONTOURA, S. M. V.; BORGHI, E.; SANTOS, F. C. DOS; KAPPES, C.; MOREIRA, S. G.; OLIVEIRA JUNIOR, A. DE; BORIN, A. L. D. B. 2016. Solos de Fertilidade Construída: características, funcionamento e manejo. Informações Agronômicas, 156. Piracicaba: IPNI. p. 1-19.

RESENDE, A. V.; GONTIJO NETO, M. M.; BORGHI, E.; SIMÃO, E. P.; MARTINS, D. C.; SANTOS, F. C.; COELHO, A. M. 2019. Nutrição e adubação do milho na região do cerrado. 
In: FLORES, R. A.; CUNHA, P. P.; MARCHÃO, R. L.; MORAES, M. F. (Ed.) Nutrição e adubação de grandes culturas na região do Cerrado. Goiânia: UFG. p. 463-502.

SÁ, J. C. M.; SÉGUY, L.; TIVET, F.; LAL, R.; BOUZINAC, S.; BORSZOWSKEI, P. R.; BRIEDIS, C.; SANTOS, J. B. DOS; HARTMAN, D. DA C.; BERTOLONI, C. G.; ROSA, J.; FRIEDRICH, T. 2015. Carbon depletion by plowing and its restoration by no-till cropping systems in oxisols of subtropical and tropical agro-ecoregions in Brazil. Land Degradation \& Development, New Jersey, v. 26, p. 531- 543. https://doi.org/10.1002/ldr.2218

SÁ, J. C. M.; SÉGUY, L.; SÁ, M. F. M.; FERREIRA, A. DE O.; BRIEDIS, C.; SANTOS, J. B. DOS; CANALLI, L. 2010. Gestão da Matéria Orgânica e da Fertilidade do Solo Visando Sistemas Sustentáveis de produção. In: PROCHNOW, L. I.; CASARIN, V.; STIPP, S. R. Boas Práticas para Uso Eficiente de Fertilizantes. Piracicaba: IPNI, ${ }^{\text {st }}$ vol. p. 383-420.

SANTOS, H. P.; FONTANELI, R. S.; PIRES, J.; LAMPERT, E. A.; VARGAS, A. M.; VERDI, A. C. 2014. Grain yield and agronomic traits in soybean according to crop rotation systems. Bragantia, Campinas, v. 73, n. 3, p. 263-273. http://dx.doi.org/10.1590/1678-4499.0136

SOUSA, D. M. G.; LOBATO, E. 2004. Cerrado: correção do solo e adubação. Brasília: Embrapa Informação Tecnológica, $2^{\text {nd }}$ ed. 416p.

TANAKA, K. S.; CRUSCIOL, C. C.; SORATTO, R. P.; MOMESSO, L.; COSTA, C. H. M.; FRANZLEUBBERS, A. J.; OLIVEIRA JUNIOR, A.; COLONEGO, J. C. 2019. Nutrients released by Urochloa cover crops prior to soybean. Nutrient Cycling in Agroecosystems, New Jersey, v. 113, p. 267-281. https://doi.org/10.1007/s10705-019-09980-5

TEIXEIRA, P. C.; DONAGEMMA, G. C.; FONTANA, A.; TEIXEIRA, W. G. 2017. Manual de métodos de análise de solo. Brasília: Embrapa, $3^{\text {rd }}$ ed. $574 \mathrm{p}$.

VELOSO, M. G.; ANGERS, D. A.; TIECHER, T.; GIACOMINI, S.; DIECKOW, J.; BAYER, C. 2018. High carbon storage in a previously degraded subtropical soil under no-tillage with legume cover crops. Agriculture, Ecosystems \& Environment, Amsterdam, v. 268, p. 1523. https://doi.org/10.1016/j.agee.2018.08.024 